\title{
Medykalizacja kobiecego ciała na przykładzie operacji plastycznych
}

\author{
MARCIN LEŹNICKI \\ Zakład Filozofii Moralnej i Bioetyki, Instytut Filozofii, \\ Uniwersytet Mikołaja Kopernika, Toruń \\ lemahr@umk.pl
}

Streszczenie. Medykalizacja człowieka, w tym także dyskutowana w ramach poniższego tekstu medykalizacja kobiecego ciała z użyciem chirurgii kosmetycznej, mimo szerokiego wachlarza deklarowanych przez naukowców korzyści, bezspornie implikuje mnogość problemów natury etyczno-prawnej, co do m.in. słuszności samej medykalizacji człowieka, możliwego kierunku jej dalszego rozwoju i prognoz z nim związanych, jak też stosowanych metod oraz środków społecznej kontroli postępującej medykalizacji. W przypadku medykalizacji kobiecego ciała z użyciem chirurgii kosmetycznej, rodzą się zaś pytania, o jej celowość, znaczenie i charakter, o rozumienie ludzkiego ciała, o kryterium piękna, czy problem estetycznego konstruowania wizerunku na podstawie idealny modelu ciała „społecznie pożądanego”. Z racji problemowej rozpiętości, jak też złożoności zjawiska medykalizacji człowieka, po zarysowaniu problemu samej medykalizacji uwaga Autora zwrócona zostanie w stroną bliższego omówienia kwestii medykalizacji kobiecego ciała z użyciem zdobyczy chirurgii kosmetycznej,z jednoczesnym wskazaniem racji przemawiających przeciwko jej stosowaniu i propagowaniu.

Stowa kluczowe: medykalizacja; normalizacja; standaryzacja; chirurgia kosmetyczna; model idealny; kontrola społeczna; ciało ludzkie.

Abstract. Medicalization of women's bodies as exemplified by plastic surgeries. Medicalization of human condition including the medicalization of women's bodies through the use of cosmetic surgery is advertised by the scientists as giving numerous benefits. At the same time, however, it undoubtedly raises many ethical and legal controversies regarding the validity of medicalization itself, possible directions of its future devel-

Scientia etFides 1(1)/2013, 213-230 
opment and the means of social control over ongoing medicalization. In the case of medicalization of women's bodies there are questions about its purpose and meaning, about the criteria of beauty and about constructing one's picture based on the ideal model of „socially desired” body. Given a broad range and complexity of medicalization of human condition the author will first give a short introduction to the problem of medicalization and then will focus on the medicalization of women's bodies through the use of cosmetic surgery whilst simultaneously giving arguments against its use and propagation.

Keywords: medicalization; normalization; standardization; cosmetic surgery; ideal model; social control; human body.

\section{Wprowadzenie}

Dynamiczny postęp naukowo-techniczny, jaki dokonuje się współcześnie w biomedycynie, ukierunkowany jest wyraźnie z jednej strony na eliminację chorób, jak też psychofizycznych dysfunkcji zdrowotnych, z drugiej zaś coraz częściej na ukierunkowane ulepszanie potencjału człowieka, w obszarach ludzkiej wydajności, jak również aktywności. Niektóre z dostępnych obecnie terapii medycznych, w tym bioingerencji, mogą już dzisiaj przyczynić się do znacznej poprawy psychofizycznej kondycji człowieka, w tym zwiększenia ludzkiej wytrzymałości, zdolności poznawczych, pamięci, korekcji postaw i zachowań, czy też kluczowej dla kultury fitness ${ }^{1}$ biotransformacji ciała ludzkiego połączonej z jego estetyzacją, wspartej potencjałem zmedykalizowanej ${ }^{2}$ chirurgii plastycznej, jak i wielu innych.

Tym niemniej zauważyć powinniśmy, że każda nowa technologia, w tym również wsparta potencjałem szeroko rozumianych nauk bioinżynieryjnych technomedycyna, która styka się z życiem ludzkim od momen-

1 Kultura fitness jest kulturą ludzkiej atrakcyjności, prężności, siły, a także wielowymiarowej wydolności, którą osiąga się w drodze zarówno intensywnych ćwiczeń, jak również biostymulacji organizmu, medycznych technik ingerencyjnych (m.in. chirurgicznych), czy też stosując biomedyczne wzmocnienia (m.in. farmaceutyczne, czy z poziomu genetyki człowieka). Marcel Verweij, "Medicalization as a moral problem for preventive medicine," Bioethics 13 (1999): 89-113; Shelly McKenzie, Getting Physical: The Rise of Fitness Culture in America (Kansas: University Press of Kansas, 2013); Peter Conrad, Valerie Leiter, "Medicalization, markets and consumers", Journal of Health and Social Behavior 45 (2004): 158-176.

2 W dalszej partii tekstu bliższe omówienie kategorii medykalizacji. 
tu jego kreacji, aż po jego kres, z jednej strony zwodzi nas coraz bardziej wymyślnymi rozwiązaniami i oferowanymi przez medycynę korzyściami, z drugiej jednak rodzi liczne pytania i obawy związane choćby z niepewnym bilansem zysków i strat, jakie trzeba będzie ponieść z tytułu jej dalszego rozwoju oraz zakrojonego na szeroką skalę wdrażania w rozległe obszary życia, kiedyś przez medycynę pomijane, dzisiaj zaś podlegające jej bezdyskusyjnej jurysdykcji, wychodząc od kontroli i regulacji „zwykłych” funkcji życiowych ludzkiego organizmu, kończąc na poddanych medykalizacji problemach natury prawno-politycznej, etyczno-moralnej czy społeczno-kulturowej. U podstaw procesu medykalizacji życia, jak zgodnie podkreślają znawcy tematu ${ }^{3}$, leży tym samym niezachwiana wiara w nieograniczone możliwości medycyny w rozwiązywaniu problemów zdrowotnych, jak i takich, które sytuują się poza autentycznym wpływem służby zdrowia, choć ta winna je sprawnie ${ }^{4}$ rozwikłać. Efektem nagłego progresu medykalizacji stało się wobec powyższego wyjaśnianie rozlicznych problemów, natury społecznej (jak choćby, alkoholizmu, narkomanii, bezrobocia, homoseksualizmu, samotności, alienacji, czy atomizacji społeczeństwa), prawnej (by przywołać kwestię przestępczości), jak również kwestii związanych z życiem prywatnym i naszą obecnością w świecie,

3 Irving K. Zola, "Medicine as an institution of social control”, Sociological Review 20 (1972): 487-504; Peter Conrad, "Medicalization and social control", Annual Review of Sociology 18 (1992): 209-232; Peter Conrad, The Medicalization of Society: On the Transformation of Human Conditions into Treatable Disorders (Baltimore: Johns Hopkins University Press, 2007); Abram de Swaan, “The reluctant imperialism of the medical profession”, Social Science and Medicine 28 (1989): 1165-1170; Ivan Illich, Limits to medicine. Medical nemesis: the expropriation of health (Harmondsworth: Penguin 1977); Ivan Illich, "The medicalization of life”, Journal of Medical Ethics 1 (1975): 73-77; Robert A. Nye, “The evolution of the concept of medicalization in the late twentieth century", Journal of History of the Behavioral Sciences 39/2 (2003): 115-129.

4 Thomas Eriksen, w książce Tyrania chwili zauważa, że żyjemy w epoce przyśpieszenia, którą charakteryzuje nagły przyrost kolejnych, następujących po sobie dynamicznie, a przez to nawarstwiających się i nakładających się na siebie zdarzeń, które należy rozwiązać szybko. Projekt naprawczej medykalizacji zakłada takie właśnie rozwiązanie, tj. nagłe, czy też pośpieszne, a przez to częstokroć bezrefleksyjne, gdyż nadmierne tempo przemian, nie sprzyja pogłębionemu namysłowi, m.in. nad ich przyczynami, wskazując jedynie, jak opanować określony skutek. Co więcej, zaczynamy przyzwyczajać się, czy też uzależniać od doraźnych, a przez to szybkich rozwiązań i wskazówek. Thomas H. Eriksen, Tyrania chwili. Szybko i wolno płynący czas w erze informacji (Warszawa: PIW, 2003). 
w tym sensem życia i zadowoleniem z niego, obłaskawieniem śmierci, problemem wieku, płci, życia seksualnego, planowaniem rodziny, pracą zawodową, relacjami międzyludzkimi i wieloma innymi. Wszystkie z przywołanych powyżej zagadnień zaczęto poddawać drobiazgowym predykacjom medycznym i takiejże kategoryzacji, w opisie zaś leczenia wskazywać interwencje (bio)medyczne jako naprawcze remedium na wszelkie „bolączki” współczesności. O ile jednak społeczna kontrola poprzez medykalizację dotyczyła kiedyś wyłącznie jednostek niebezpiecznych, zaburzonych, patologicznych, czy też dewiantów, o tyle współcześnie kontrola medyczna, w ramach prowadzonej polityki zdrowia publicznego, objęła swoim zasięgiem wszelkie przejawy ludzkiego życia. Te zaś diagnozować zaczęto w kategoriach medycznych, jako dysfunkcje, którym należy zapobiegać.

\section{Typologia medykalizacji}

Jednoznaczne zdefiniowanie pojęcia medykalizacji, jak również precyzyjne wskazanie prekluzyjnego katalogu problemów lokujących się w obszarze jej oddziaływania nastręcza naukowcom licznych trudności, wynikłych m.in. z płynności definicyjnej wzmiankowanego pojęcia, a przez to jego otwartości, którą to próbuje się przezwyciężyć, uzupełniając rzeczone pojęcie o kolejne dane napływające z obszaru dynamicznie rozwijającej się technonaukowej ${ }^{5}$ medycyny, z uwzględnieniem szerokozakresowego kontekstu społecznego.

Pomimo niejednorodnego definiowania medykalizacji zauważyć możemy, że stanowi ona przykład wielowątkowego oraz interdyscyplinarnego procesu, który śledzić można m.in. w obszarze socjologii, filozofii, (bio) etyki, antropologii, politologii, czy chociażby prawa, kiedy to podejmuje się przykładowo dyskurs nad biowładzą oraz biopolityką, dla których kategoria medykalizacji pełni kluczową rolę. To wreszcie szeroko rozumiany proces,

5 Termin technonauka wprowadzony został do literatury przedmiotu przez Brunona Latoura, por. Brunon Latour, Science in Action. How to Follow Scientists and Engineers Through Society (Cambridge: Harvard University Press, 2003, 174-175). 
w wyniku którego pewne rejony życia społecznego, które dotychczas znajdowały się poza zainteresowaniem biowładzy (czy też władzy medycznej) stały się domeną szerokozakresowej medycyny, która je „skolonizowała” i rozpoznała w konstrukcji, jako problemy natury medycznej ${ }^{6}$. Definiując zjawisko medykalizacji, podkreślić należy zatem, że stanowi ona proces, w wyniku którego coraz więcej aspektów życia codziennego przeszło pod kontrolę, wpływ i nadzór medycyny ${ }^{7}$. Inni badacze opisują medykalizację, jako proces ostateczny, w ramach którego wszelkie bez wyjątku problemy społeczne określa się jako medyczne, czy wręcz patologiczne ${ }^{8}$. Według rzeczonych badaczy, istnieją czynniki kontekstowe, które sprzyjają wzrostowi znaczenia i siły medykalizacji, ta zaś musi je przezwyciężyć.

Wśród głównych czynników, które przyczyniły się do narodzin medykalizacji wymienia się m.in. spadek religijności, laicyzację, niezachwianą wiarę w postęp naukowo-techiczny, wzrost znaczenia indywidualizmu, atomizację społeczeństwa i osłabienia więzi społecznych, narastającą alienację, racjonalizację, prymat medycyny, jak również autorytet lekarza, który jako „kontroler naszego życia”, władny jest je operacjonalizować, kontrolować, czy wreszcie zarządzać (nim), a w ramach wdrażanej coraz intensywniej medycyny naprawczej wskazywać znamiona przypadłości zdrowotnej występujące po stronie danego zjawiska społecznego oraz najszybszy sposób ich eliminacji.

Tak rozumiane zjawisko medykalizacji, wywołuje jednak zrozumiały niepokój i sprzeciw, wskazuje się na jego pejoratywny wydźwięk i stosuje w kontekście krytycznym, wobec zbyt daleko idącego wpływu nauk medycznych, które zawłaszczyły i skolonizowały życie ludzkie, wyjaśniając przy tym zjawiska z obszaru nauk pozamedycznych, definiując kategorię normy, normalności i nienormalności, standardu, patologii, dewiacji, ano-

6 Mark Walsh, Introduction to sociology for health carers (Cheltenham: Nelson Thornes, 2004).

7 Irving K. Zola, Socio-medical inquiries: Recollections, reflections and reconsiderations (Philadelphia: Temple University Press, 1983), 295.

8 David Cohen, Peter R. Breggin, Your drug may be your problem (Cambridge, MA: Perseus Books, 1999); Christian Saint-Germain, Paxil blues (Montreal, QC: Les Éditions du Boréal, 2005). 
malii, dysfunkcji, jak i wielu innych. Jako realne zagrożenia związane z rozwojem medykalizacji wskazuje się również szybki wzrost naddiagnostyki i nadrozpoznania, które narażają pacjentów na niepotrzebne i obciążające ich w sensie psychofizycznym leczenie, generując przy tym redundantne koszty leczenia, przy zawyżonym wskaźniku wyleczeń. Jako uboczny skutek rozwoju medykalizacji i leżącej u jej podstaw naddiagnostyki wskazuje się także, „szarlatanizm medyczny”, w tym dyskusyjne kreowanie nowych chorób, testów i leków na przypadłości, które dotąd bądź to nie były domeną służby zdrowia, bądź też nie wymagają leczenia (jak choćby przeziębienie, okresowe osłabienie, złe samopoczucie, czy sporadyczny ból głowy), „chorób dla zysku” (jak w przypadku otyłości), czy wreszcie wprowadzenie tzw. terapii alternatywnych (których ilustracją niech będzie detoks i homeopatia). U podstaw niegasnącej w ludziach wiary w moc medycyny, która zwalczy wszystkie ze wspomnianych powyżej przypadłości i chorób, tak realnych, jak i nierealnych, leży tymczasem wytwarzana i nieustannie podsycana przez instytucję zdrowia publicznego wiara w „Happy Pills”, pigułkę szczęścia, magiczny specyfik, terapię na każdą przypadłość, dysfunkcję, czy jakąkolwiek chorobę.

Niewątpliwie jednak zastosowane po raz pierwszy przez Michaela Foucaulta w 1963 roku $^{9}$ pojęcie medykalizacji zrobiło „oszałamiającą karierę”, za czym przemawiać może chociażby obszerna typologia wzmiankowanego pojęcia, co obrazuje poniższy diagram.

W ramach zarysowanej powyżej typologii medykalizacji zauważyć można, że została ona podzielona ze względu, na:

a) wcześniejszy, bądź też późniejszy okres jej zastosowania w organizmie ludzkim. Jako przekład medykalizacji wczesnej posłużyć może np. użycie wzmocnień genetycznych ${ }^{10}$, służących poprawie natury człowieka (kons-

9 W pracy naukowej Naissance de la clinique. Une archéologie du regard medical. [przekład polski: Michel Foucault, Narodziny kliniki (Warszawa: Wydawnictwo KR, 1999)].

10 Jason Borenstein, “The Wisdom of Caution: Genetic Enhancement and Future Children”, Sci Eng Ethics 15 (2009): 517-530; Nick Bostrom, "Human Genetic Enhancements: A Transhumanist Perspective”, Journal of Value Inquiry 37/4 (2003): 493-506, Edwin Etieyibo, "Genetic enhancement, social justice, and welfare-oriented patterns of distribution", Bioethics 26/6 (2011): 296-304; Martin Gunderson, "Genetic Engineering and the Consent 


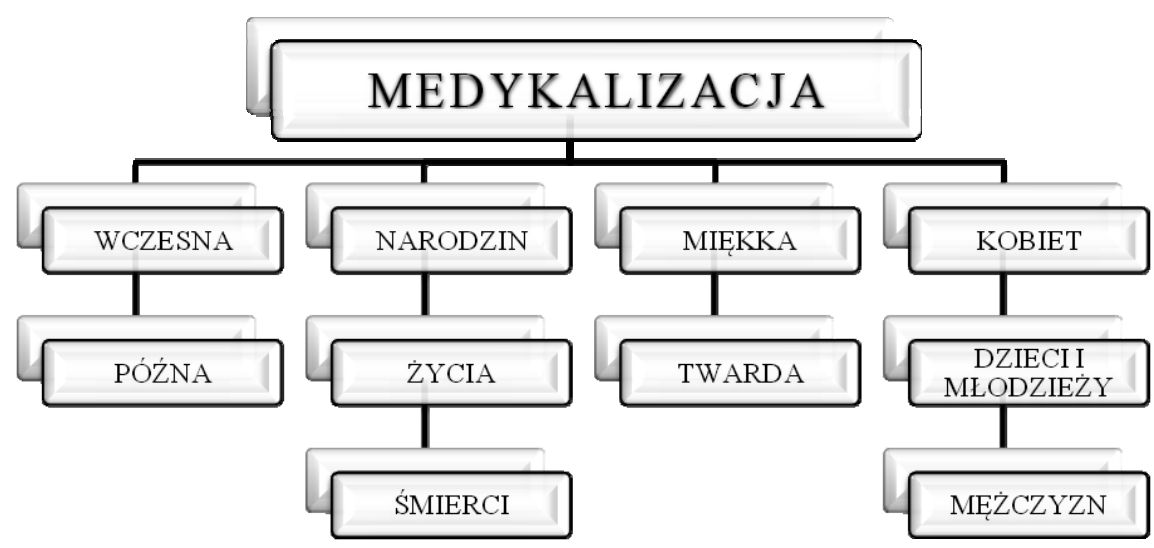

Diagram 1. Typologia medykalizacji

tytucji genetycznej organizmu) wyjściowo zdrowego na inicjacyjnym etapie rozwojowym, celem optymalizacji jego wydajności. W przypadku medykalizacji późnej wskazać można wszelkie działania (bio)medyczne, które służą medycznej korekcji organizmu ludzkiego na dalszym etapie rozwojowym i dotyczą problemów, które zostają stopniowo objęte medycznym zainteresowaniem, jak na przykład, emocje ${ }^{11}$ (w obszarze behawioru), płeć ${ }^{12}$, dzieciństwo ${ }^{13}$, rodzina ${ }^{14}$ i wiele innych;

of Future Persons”, Journal of Evolution and Technology 18/1 (2008): 86-93; David Plotz, Fabryka Geniuszów. Niezwykła historia banku spermy noblistów (Warszawa: Świat Książki, 2007); John A. Robertson, Children of Choice: Freedom and the New Reproductive Technologies (Princeton: Princeton University Press, 1994).

${ }_{11}$ James M Wilce, Language and Emotion. Studies in the Social and Cultural Foundations of Language (Cambridge: Cambridge University Press, 2009).

12 Catherine K. Riessman, "Women and Medicalization: A New Perspective", Soc Policy 14/1 (1983): 3-18; Elianne Riska, “Gendering the Medicalization Thesis”, Advances in Gender Research 10/7 (2003): 59-87.

13 Sami Timimi, Pathological Child Psychiatry and the Medicalization of Childhood (Hove: Brunner-Routledge, 2002).

14 Kaja Finkler, "The kin of the gene: the medicalization of family and kinship in American Society”, Curr Anthropol. 42/2 (2001): 235-63. 
b) w ramach drugiego podziału medykalizacji, spowinowaconego skądinąd z pierwszym, bierze się pod uwagę naturalną rytmikę ludzkiego życia i wskazuje, że medykalizacja powiązana jest z określoną faza życia ludzkiego, tj. wczesną, jak również późną, przy czym te dodatkowo dzieli się na medykalizację okresu inicjacyjnego życia ludzkiego, przypadającą na okres embriogenezy i wczesny etap życia ludzkiego; okres przebiegu życia ludzkiego, który trwać może w sposób niezakłócony, aż do śmierci oraz ostatni etap życia ludzkiego, który wiązać należy z postępującym procesem starzenia i śmierci. W kolejności przedstawionych powyżej i następujących po sobie etapów życia, zaczęto zatem wyróżniać medykalizację narodzin ${ }^{15}, \dot{z} y$ cia $^{16}$, jak również śmierci i umierania ${ }^{17}$. W ramach tych wyróżniono z kolei katalog problemów szczegółowych, które należy poddać medykalizacji, jak choćby przebieg i monitorowanie narodzin, ból i cierpienie towarzyszące procesowi starzenia, radzenie sobie z cierpieniem, opieka nad pacjentami przewlekle chorymi, projekty suicydologiczno-eutanatyczne itp.;

c) kolejny podział medykalizacji na tzw. medykalizację miękkq oraz twardq uzależniony został od stopnia komplikacji interwencji biomedycznej w organizm, przy jednoczesnej prognozowanej skali dolegliwość, jaka może wiązać się z zastosowaniem rzeczonej interwencji, bądź też biomedycznej ingerencji ${ }^{18}$. Warto jednak nadmienić, że nie ma powszechnej zgody, co do stosowania pojęcia medykalizacji miękkiej i twardej;

d) ostatni z zaproponowanych powyżej podziałów medykalizacji uzależniony jest od obranego pod medykalizację „fizycznego obiektu” jej zainteresowania. I tak, zgodnie z funkcjonującym podziałem, mówić możemy,

15 Bonnie Fox, Diana Worts, "Revisiting the Critique of Medicalized Childbirth: A Contribution to the Sociology of Birth”, Gender and Society 13/3 (1999): 326-346; Heather A. Cahill, "Male appropriation and medicalization of childbirth: an historical analysis", Journal of Advanced Nursing 33/3 (2001): 334-342.

16 Ivan Illich, "The medicalization of life” [...], Ben Goldacre, “The Medicalisation of Everyday Life”, accessed July 12, 2008, http://www.badscience.net/2008/09/the-medicalisation-of-everyday-life.

17 Marcella Colbert, “The Medicalization of Death \& Dying”, accessed June 06, 2011 http:// www.uffl.org/Vol14/colbert-04.pdf; David Clark, "Between hope and acceptance: the medicalisation of dying”, BMJ 324/7342 (2002): 905-907.

18 Por. Robert A. Donnelly, Immigrants and Health Agency: Public Safety, Health, and Latino Immigrants in North (Carolina: CCSI Working Paper \#128, 2005). 
o medykalizacji kobiet ${ }^{19}$, mężczyzn ${ }^{20}$, jak również dzieci $i$ młodzież $y^{21}$. W ramach natomiast poszczególnych jej typów wskazuje się obszary problemowe, które mają zostać poddane medykalizacji. I tak w przypadku medykalizacji kobiet, medykalizacji poddano menopauzę (poprzez farmakologizację), kobiece zaburzenia seksualne FSD, macierzyństwo, ciążę oraz poród, ciało (z użyciem operacji plastycznych), czy choćby menstruację. W przypadku mężczyzn przedmiotem zainteresowania interwencji medycznych stały się andropauza, impotencja, problemy seksualne, w tym zaburzenia erekcji ED, klimakterium, czy też łysienie. W przypadku dzieci i młodzieży medykalizacja objęła swoim zasięgiem

19 Patricia A. Kaufert, Margaret Lock, “Medicalization of women's third age”, J Psychosom Obstet Gynaecol. 18/2 (1997): 81-86; Farrell Janine, Cacchioni Thea, "The medicalization of women's sexual pain”, J Sex Res. 49/4 (2012): 328-336; Rima D. Apple, Mothers and Medicine: A Social History of Infant Feeding (Madison, WI: The University of Wisconsin Press, 1987); Katherine Arnup, Education for Motherhood: Advice for Mothers in Twentieth Century Canada (Toronto: University of Toronto Press, 1994); Rima D. Apple, "Constructing mothers: Scientific motherhood in the nineteenth and twentieth centuries", Social History of Medicine 8/2 (1995): 161-178; Joy Noel-Weiss, Medicalizing Motherhood: Maternity Care in Canada in the 1920s and 1930s, accessed May 12, 2009, http://www.asklenore.info/parenting/resources/maternity_care.pdf; Agnieszka Gromkowska-Melosik, Kobieta epoki wiktoriańskiej. Tożsamość, ciało i medykalizacja (Kraków: Oficyna Wydawnicza „Impuls”, 2013); John Bancroft, "The Medicalization of Female Sexual Dysfunction: The Need for Caution”, Archives of Sexual Behavior 31/5 (2002): 451-455; Bell Susan "Changing ideas: the medicalisation of menopause", Social Science and Medicine 24/6 (1987): 535-542; Patricia A. Kaufert, Penny Gilbert, "Women, menopause, and medicalization", Culture, Medicine and Psychiatry 10/1 (1986): 7-21;

20 Elizabeth S. Watkins, "The Medicalisation of Male Menopause in America”, Social History of Medicine 20/2 (2007): 369-388; Leonore Tiefer, "The Medicalization of Impotence: Normalizing Phallocentrism", Gender and Society 8/3 (1994): 363-377; Loe Meika, The Rise of Viagra: How the Little Blue Pill Changed Sex in America (New York: New York University Press, 2004); Richard M. Carpiano, "Passive medicalization: The Case of Viagra and Erectile Dysfunction”, Sociological Spectrum: Mid-South Sociological Association 21/3 (2001): 441-450.

${ }^{21}$ Kristján Kristjánsson, “Medicalised pupils: the case of ADD/ADHD”, Oxford Review of Education 35/1 (2009): 111-127; Peter Conrad, Deborah Potter, "From Hyperactive Children to ADHD Adults: Observations on the Expansion of Medical Categories," Social Problems 47 (2000): 559-582; Henrikje Klasen, "A Name, What's in a Name? The Medicalization of Hyperactivity, Revisited," Harvard Rev Psychiatry 7 (2000): 334-344; Derek Summerfield, "The invention of post-traumatic stress disorder and the social usefulness of a psychiatric category”, British Medical Journal 322 (2001): 95-98; Susie Scott, „The medicalisation of shyness: from social misfits to social fitness", Sociology of Health \& Illness 28/2 (2006): $133-153$. 
takie dysfunkcje zdrowotne, jak: ADHD, ADD, stany lękowe, bezsenność, anoreksję, dyslekcję, nieśmiałość i wiele innych.

Jak łatwo można zauważyć z tego, co zostało powiedziane wyżej, obszar zainteresowania medykalizacji jest niesłychanie rozległy. Dlatego też w dalszej części artykułu prześledzony zostanie bliżej problem medykalizacji kobiet z użyciem operacji plastycznych. W literaturze przedmiotu uznawany jest on bowiem za reprezentatywny dla poruszanego w pracy problemu medykalizacji człowieka, a baczny obserwator życia publicznego najpewniej dostrzeże jego niedającą się przemilczeć wszechobecność, w prowadzonej społecznie debacie poświęconej estetyce współczesnego człowieka.

\section{Medykalizacja (kobiecego) ciała z użyciem operacji plastycznych}

Medykalizacja ludzkiego ciała stała się faktem. Te natomiast, z racji swej „miękkości oraz plastyczności”, jak zauważa Amnon J. Suissa ${ }^{22}$, podlega ciągłej redefinicji społecznego rozumienia, w czym pomaga medycyna wsparta potencjałem ekonomii i polityki ${ }^{23}$. Chirurgia plastyczna i dokonywana w jej ramach medykalizacja organów stanowi wobec powyższego wyraz kontroli społecznej i zarządzania ciałem ludzkim, na poziomie zarówno fizycznym, jak też społecznym. Fizycznym, jako że operacje plastyczne pozwalają modyfikować zewnętrzne przejawy ludzkiej cielesności, jak twarz, piersi, nogi, brzuch, nos itd. Społecznym, ponieważ wskazują one akceptowalny, czy też społecznie pożądany model idealnego ciała (ludzkiego), jako model znormalizowany i zestandaryzowany. Ten zaś konstruowany jest w stanowiących środek społecznej kontroli gabinetach chirurgii estetycznej. Medykalizacja ludzkiego ciała z użyciem chirurgii plastycznej, jak zauważa Blum, normalizuje, wobec powyższego estetyczne kryterium piękna ${ }^{24}$ i wyznacza kierunek dla przyszłej, ujednoliconej estetyki ciała ludzkiego.

22 Amnon J. Suissa, "Addiction to Cosmetic Surgery: Representations and Medicalization of the Body”, Int J Ment Health Addiction 6 (2008): 619-630.

23 A precyzyjniej bioekonomii i biopolityki.

24 Virginia L. Blum, Flesh wounds: The culture of cosmetic surgery (Berkeley, CA: University of California Press, 2003). 
Problem korekcji ciała jest szczególnie pilny dzisiaj, kiedy to narasta niezadowolenie z obrazowania własnego ciała oraz jego odzwierciedlenia, zastana cielesność jest negowana i odrzucana, a wśród licznych dysfunkcji zdrowotnych wskazuje się zaburzenia dysmorfobiczne DSM-IV. Warto przy tym dodać, że już Freud zauważał, że problem obrazowania własnego ciała stanowi jedną z podstawowych bolączek cywilizacji ${ }^{25}$. Wobec powyższego ciało oddano pod opiekę lekarzy, którzy zaczęli je stopniowo medykalizować, tj. opanowywać w czasie ${ }^{26}$, nadzorować ${ }^{27}$ i konstruować ${ }^{28}$, na każdym etapie ludzkiego życia, od narodzin aż do śmierci, wciąż rozszerzając zakres „wskazanych” ingerencji biomedycznych, w tym chirurgicznych. To zaś doprowadziło do postawienia pytań m.in. o to, czy istnieją stałe reprezentacje ciała w historii?, czy operacje plastyczne zawsze są zjawiskiem pożądanym?, czy istnieje jakakolwiek granica medykalizacji organów, szerzej zaś ciała ludzkiego?, a wreszcie, na czym miałaby polegać kontrola społeczna z użyciem zdobyczy medycyny plastycznej, w dobie postępującej demokratyzacji ludzkiej anatomii? ${ }^{29}$, jak i wielu innych.

U podłoża postawionych powyżej pytań lokuje się tymczasem nierozstrzygalny problem postrzegania ludzkiego ciała, czy też społeczno-kulturowego jego wartościowania.

Przykładowo, w Brazylii, Wenezueli, Argentynie oraz Chile operacje plastyczne cieszą się znacznym uznaniem społecznym, są szeroko akceptowalne i zinstytucjonalizowane. W Iranie, czy choćby Arabii Saudyjskiej korzystanie z operacji plastycznych jest surowo zabronione, same zaś zabiegi

${ }_{25}$ Por. Zygmunt Freud, Kultura jako źródło cierpień (Warszawa: Wydawnictwo KR, 1992).

26 Nicolas Moreau, Florence Vinit, “Empreintes de corps: éléments de repères dans l'histoire de la médicalisation”, Nouvelles Pratiques Sociales 19 (2007), 34-45.

27 Kathryn P. Morgan, "Woman and the Knife: Cosmetic Surgery and the Colonization of Women`s Bodies”, Hypatia 6/3 (1991): 26-53.

28 Anna Arroba, “The medicalization of women's bodies in the era of globalization”, Women's Health Journal 1 (2003): 38-42; Elizabeth Klaver, The Body in Medical Culture (Albany: SUNY Press, 2009); Franca Pizzini, “The medicalization of women's body”, accessed June 11, 2007, http://www.women.it/quarta/workshops/epistemological4/pizzini.htm

${ }^{29}$ Jako przykład demokratyzacji ludzkiej anatomii podać można chociażby udostępnione szerokiej publiczności wystawy plastynacji autorstwa Von Hagensa, [patrz:] Günther Von Hagens, Angelina Whalley, Le monde du corps: exposition anatomique des corps humains véritables (Paris: Éditions Arts et Sciences, 2005). 
traktuje się jako wyraz najwyższej dewiacji czy przestępstwa. W Chinach i Korei Południowej widoczny jest znaczny wzrost zainteresowania chirurgią plastyczną od początku XX wieku ${ }^{30}$, co było spowodowane, po pierwsze, traktowaniem jej jako inwestycji społeczno-ekonomicznej w małżeństwo z potencjalnie zamożniejszym partnerem, po drugie zaś szeroką dostępnością rozlicznych klinik chirurgii estetycznych przyjmujących również „poza bezpośrednim wskazaniem zdrowotnym”. Najwyższy, odnotowany w przeciągu ostatnich kilkudziesięciu lat, wskaźnik przeprowadzonych operacji kosmetycznych wykazują Stany Zjednoczone, Japonia i Brazylia ${ }^{31}$, co wiązać należy przede wszystkim z utrzymującą się, by nie powiedzieć, że rosnącą w tych państwach obawą o utrzymanie dobrego wizerunku (Selfimage). Jak pokazują liczne badania naukowe, państwa te próbują sprostać narastającej fali dysmorficznych zaburzeń ciała (BDD), zaburzeń obsesyjno-kompulsyjnych (OCD), w tym choćby anoreksji i coraz silniejszej społecznej potrzebie naturalizacji, czy standardyzacji ciała z zastosowaniem tzw. „zabiegów kompleksowych", z założenia multiproceduralnych, w ramach, których podczas jednej operacji przeprowadza się wiele procedur chirurgicznych, w tym m.in. przebudowę, odsysanie, wypełnianie, naciąganie, czy choćby regenerację skóry, botoks, zabiegi protetyczno-implantacyjne, które poprzedzić można (selektywną) reorientacją układu kostnego (w tym, np. korekcją żuchwy oraz żeber), uzupełnioną o plastykę narządów rodnych (w tym plastykę warg sromowych $\mathrm{u}$ kobiet oraz penisa u mężczyzn, $\mathrm{z}$ jednoczesną możliwością podniesienia jąder), a wreszcie z pełną korekcją wyglądu całego naszego ciała, w tym stylizacją twarzy, piersi, brzucha, kończyn, jak również pośladków.

W obliczu aktywnie rozwijającej się estetycznej chirurgii plastycznej zaczęto podkreślać jej pozytywy, jak również negatywy.

Wśród ewidentnych plusów chirurgii plastycznej wskazano na przykład, że człowiek, który wyraża zgodę na ingerencje medyczne, w tym chirurgiczne, z jednej strony dąży do szerszej integracji, jak też akceptacji społecznej,

${ }_{30}$ Charles Scanlon, The price of beauty in South Korea (BBC News, South Korea, 2005).

31 Naomi Wolf, The Beauty Myth: How Images of Beauty Are Used Against Women (New York: HarperCollins, 2002). 
w dobie poszerzającego się dystansu społecznego, z drugiej zaś umożliwiają mu one utrzymanie niepowtarzalnej tożsamości, wyjątkowości, czy też odrębności, swojkkości, wierności wizerunkowi samego sobie ${ }^{32}$ (choćby i wytworzonemu) i przełamaniu „syndromu samowykluczenia” (selfexclusion syndrom). Chirurgia plastyczna stanowić może nadto odpowiedź na zakorzenioną w kulturze zachodniej społeczną potrzebę piękna, w tym też piękna ludzkiego ciała, które przy jej pomocy można poddawać procesowi konstruowania i renegocjacji, w tym hybrydyzacji33, czy choćby morfingowi.

Rozliczni przeciwnicy medykalizacji ciała z użyciem operacji chirurgicznych zaczęli tymczasem podkreślać m.in. uzależnienie od chirurgii estetycznej człowieka ${ }^{34}$, który w poczuciu własnej niedoskonałości nigdy $z$ niej nie zrezygnuje, co też przekładać się będzie na dalsze negatywne skutki zdrowotne, społeczne (w tym zaburzenia psychospołeczne) i ekonomiczne. Przykładowo, David Le Breton zauważa przy tym, że poczucia niestabilności, zaburzeń tożsamości, pustki życiowej i obaw przed nią nie wypełnią operacje plastyczne, które regularnie trzeba powtarzać, ponieważ nie oferują one efektu ostatecznego, a jedynie rozwiązanie czasowe ${ }^{35}$. Na uzależnienie od zabiegów z zakresu chirurgii estetycznej wpływ mają ponadto indoktrynacja w mass mediach ${ }^{36}$, niezachwiana wiara społeczeństwa we wszechmoc technologii, na co m.in. uwagę zwracają John i Nana Naisbitt, jak też Douglas Philip ${ }^{37}$, a także proces socjalizacji estetycznej, w ramach którego wyrażono szerokie poparcie dla zdobyczy współczesnej skomercjalizowanej biomedycyny (w tym również chirurgii estetycznej), która bezpośrednio przyczyniła się do kulturowej reprodukcji kobiecości.

32 Pierre-Luc Saint-Hilaire, De l'usage “plastique” des antidépresseurs. Johanne Collin, Marcelo Otéro, Laurence Monnais (Eds.), Le médicament au coeur de la socialité contemporaine (pp. 109-125). (Quebec, QC: Presses de l'université du Québec, 2006, 111-112).

33 Muriel Darmon, Christine Détrez, Corps et société: Problèmes politiques et sociaux (Paris: La documentation française, 2004, 5).

34 Amnon J. Suissa, "Addiction to Cosmetic Surgery: Representations and Medicalization of the Body", Int J Ment Health Addiction 6 (2008): 626-629.

35 David Le Breton, Les passions ordinaires (Paris: Petite bibliothèque Payot, 2004).

36 Michelle A. Abate, "Plastic Makes Perfect”: My Beautiful Mommy, Cosmetic Surgery, And The Medicalization Of Motherhood, Women's Studies 39 (2010): 720.

37 John Naisbitt, Nana Naisbitt, Douglas Philips, High Tech. High Touch. Technologia a poszukiwanie sensu (Poznań: Wydawnictwo Zysk i S-ka, 2003). 
Przedchirurgiczne ciało uznane zostało ostatecznie za gorsze, do poprawy i jak zauważyła Michelle Ann Abate ${ }^{38}$, winno się je poddać korekcji, już na wczesnym etapie życia (stąd karnety do salonów odnowy biologicznej dla dzieci). Warto równocześnie dodać, za przywołaną powyżej badaczką, iż mimo znacznej inwazyjności zabiegów chirurgicznych, bagatelizuje się informacje o efektach ubocznych zabiegów kosmetycznych, jak choćby defragmentacji skóry, jej guzowatości, zmniejszonej jej wrażliwości (np. w okolicy sutków), przekrwieniu i stwardnieniu piersi, obrzękach, mogącej się pojawić asymetrii piersi, wyciekach oraz pęknięciach skórnych, zapadnięciu się implantu, osłabieniu układu odpornościowego, w tym pojawieniu się tocznia, zapaleniu tkanki łącznej, możliwości pojawienia się zmian nowotworowych, zapaleniu mózgu, utrzymującego się bólu pooperacyjnego, o którym placówki odnowy biologicznej wolą nie wspominać, czy wreszcie zmianom bliznowatym u pacjentek. Co więcej, bardzo często wspomniane zabiegi należy powtarzać, bez pewności osiągnięcia zamierzonego efektu.

Powyżej omówione kwestie niewątpliwie są istotne dla prowadzonej aktualnie debaty poświęconej złożonemu i wieloaspektowemu problemowi medykalizacji człowieka. Tę zaś, z racji wielości odmian, typów i podtypów, jak w przypadku medykalizacji ciała kobiecego, dyskutować można, m.in. w kontekście medycznym, społecznym, kulturowym, prawno-legislacyjnym, etyczno-moralnym, w ramach danej tradycji, religii, i wielu innych.

\section{Bibliografia}

Abate, Michelle A. 2010. “«Plastic Makes Perfect»: My Beautiful Mommy, Cosmetic Surgery, And The Medicalization Of Motherhood.” Women's Studies 39: 715-746. DOI: http://dx.doi.org/10.1080/00497878.2010.505152

Apple, Rima D. 1995. "Constructing mothers: Scientific motherhood in the nineteenth and twentieth centuries." Social History of Medicine 8/2: 161-178.

38 Michelle A. Abate, “«Plastic Makes Perfect»: My Beautiful Mommy, Cosmetic Surgery, And The Medicalization of Motherhood”, Women's Studies 39 (2010): 728-738. 
Apple, Rima D. 1987. Mothers and Medicine: A Social History of Infant Feeding. Madison, WI: The University of Wisconsin Press.

Arnup. Katherine. 1994. Education for Motherhood: Advice for Mothers in Twentieth Century Canada. Toronto: University of Toronto Press.

Arroba, Anna. 2003. “The medicalization of women's bodies in the era of globalization.” Women's Health Journal 1: 38-42.

Bancroft, John. 2002. "The Medicalization of Female Sexual Dysfunction: The Need for Caution.” Archives of Sexual Behavior 31/5: 451-455.

Bell, Susan. 1987. "Changing ideas: the medicalisation of menopause.” Social Science and Medicine 24/6: 535-542.

Blum, Virginia L. 2003. Flesh wounds: The culture of cosmetic surgery. Berkeley, CA: University of California Press.

Borenstein, Jason. 2009. “The Wisdom of Caution: Genetic Enhancement and Future Children.” Sci Eng Ethics 15: 517-530, DOI: http://dx.doi.org/10.1007/ s11948-009-9183-9

Bostrom, Nick. 2003. "Human Genetic Enhancements: A Transhumanist Perspective." Journal of Value Inquiry 37/4: 493-506.

Cahill, Heather A. 2001. "Male appropriation and medicalization of childbirth: an historical analysis." Journal of Advanced Nursing 33/3: 334-342.

Carpiano, Richard M. 2001. "Passive medicalization: The Case of Viagra and Erectile Dysfunction.” Sociological Spectrum: Mid-South Sociological Association 21/3: 441-450. DOI: http://dx.doi.org/10.1080/027321701300202082

Clark, David. 2002. "Between hope and acceptance: the medicalisation of dying.” BMJ 324/7342: 905-907. DOI: http://dx.doi.org/10.1136/bmj.324.7342.905

Cohen, David, Breggin, Peter R. 1999. Your drug may be your problem. Cambridge, MA: Perseus Books, 1999.

Colbert, Marcella. 2011. “The Medicalization of Death \& Dying.” Accessed June 06. http://www.uffl.org/Vol14/colbert-04.pdf

Conrad, Peter. 1992. "Medicalization and social control." Annual Review of Sociology 18: 209-232. DOI: http://dx.doi.org/10.1146/annurev.so.18.080192.001233

-. 2007. The Medicalization of Society: On the Transformation of Human Conditions into Treatable Disorders. Baltimore: Johns Hopkins University Press.

Conrad, Peter, Leiter, Valerie. 2004. “Medicalization, markets and consumers.” Journal of Health and Social Behavior 45: 158-176.

Conrad, Peter, Potter, Deborah. 2000. "From Hyperactive Children to ADHD Adults: Observations on the Expansion of Medical Categories.” Social Problems 47: 559-582. DOI: http://dx.doi.org/10.2307/3097135 
Darmon, Muriel, Détrez, Christine.2004. Corps et société: Problèmes politiques et sociaux. Paris: La documentation française, 5.

Donnelly, Robert A. 2005. Immigrants and Health Agency: Public Safety, Health, and Latino Immigrants in North. Carolina: CCSI Working Paper \#128.

Eriksen Thomas H. 2003. Tyrania chwili. Szybko i wolno płynący czas $w$ erze informacji. Warszawa: PIW.

Etieyibo, Edwin. 2011. "Genetic enhancement, social justice, and welfare-oriented patterns of distribution.” Bioethics 26/6: 296-304. DOI: http://dx.doi. org/10.1111/j.1467-8519.2010.01872.x

Farrell, Janine, Cacchioni, Thea. 2012. “The medicalization of women's sexual pain.” J Sex Res. 49/4: 328-336. http://dx.doi.org/10.1080/00224499.2012.688227

Finkler, Kaja. 2001. "The kin of the gene: the medicalization of family and kinship in American Society.” Curr Anthropol. 42/2: 235-63. DOI: http://dx.doi. org/10.1086/320004

Foucault, Michel. 1999. Narodziny kliniki. Warszawa: Wydawnictwo KR.

Fox, Bonnie, Worts, Diana. 1999. "Revisiting the Critique of Medicalized Childbirth: A Contribution to the Sociology of Birth." Gender and Society 13/3: 326-346. DOI: http://dx.doi.org/10.1177/089124399013003004

Freud, Zygmunt. 1992. Kultura jako źródło cierpień. Warszawa: Wydawnictwo KR.

Goldacre, Ben. 2008. “The Medicalisation of Everyday Life.” Accessed July 12. http:// www.badscience.net/2008/09/the-medicalisation-of-everyday-life

Gromkowska-Melosik, Agnieszka. 2013. Kobieta epoki wiktoriańskiej. Tożsamość, ciało i medykalizacja. Kraków: Oficyna Wydawnicza „Impuls.

Gunderson, Martin. 2008. "Genetic Engineering and the Consent of Future Persons”. Journal of Evolution and Technology 18/1: 86-93.

Illich, Ivan. 1975. “The medicalization of life.” Journal of Medical Ethics 1: 73-77. DOI: http://dx.doi.org/10.1136/jme.1.2.73

-. 1977. Limits to medicine. Medical nemesis: the expropriation of health. Harmondsworth: Penguin.

Kaufert, Patricia A., Gilbert, Penny. 1986. “Women, menopause, and medicalization.” Culture, Medicine and Psychiatry 10/1: 7-21. DOI: http://dx.doi. org/10.1007/BF00053260

Kaufert, Patricia A., Lock, Margaret. 1997. “Medicalization of women's third age.” J Psychosom Obstet Gynaecol. 18/2: 81-86. DOI: http://dx.doi.org/10.3109/ 01674829709085573

Klasen, Henrikje. 2000. “A Name, What's in a Name? The Medicalization of Hyperactivity, Revisited.” Harvard Rev Psychiatry 7: 334-344. DOI: http://dx.doi. org/10.1093/hrp/7.6.334 
Klaver, Elizabeth, 2009. The Body in Medical Culture. Albany: SUNY Press.

Kristjánsson, Kristján. 2009."Medicalised pupils: the case of ADD/ADHD.” Oxford Review of Education 35/1: 111-127. DOI: http://dx.doi.org/10.1080/03054980802417354

Latour, Brunon. 2003. Science in Action. How to Follow Scientists and Engineers Through Society. Cambridge: Harvard University Press.

Le Breton, David. 2004. Les passions ordinaires. Paris: Petite bibliothèque Payot.

McKenzie Shelly. 2013. Getting Physical: The Rise of Fitness Culture in America. Kansas: University Press of Kansas.

Meika, Loe. 2004. The Rise of Viagra: How the Little Blue Pill Changed Sex in America. New York: New York University Press.

Moreau, Nicolas, Vinit, Florence. 2007 ."Empreintes de corps: éléments de repères dans l'histoire de la médicalisation.” Nouvelles Pratiques Sociales 19, 34-45. DOI: http://dx.doi.org/10.7202/016049ar

Morgan, Kathryn P. 1991. "Woman and the Knife: Cosmetic Surgery and the Colonization of Women`s Bodies”. Hypatia 6/3: 26-53.

Naisbitt, John, Naisbitt, Nana, Philips, Douglas. 2003. High Tech. High Touch. Technologia a poszukiwanie sensu. Poznań: Wydawnictwo Zysk i S-ka.

Noel-Weiss, Joy. 2009. Medicalizing Motherhood: Maternity Care in Canada in the 1920s and 1930s. Accessed May 12. http://www.asklenore.info/parenting/resources/maternity_care.pdf 1

Nye, Robert A. 2003. "The evolution of the concept of medicalization in the late twentieth century." Journal of History of the Behavioral Sciences 39/2: 115-129. DOI: http://dx.doi.org/10.1002/jhbs.10108

Pizzini, Franca. 2007. “The medicalization of women's body”. Accessed June 11, 2007, http://www.women.it/quarta/workshops/epistemological4/pizzini.htm

Plotz. David. 2007. Fabryka Geniuszów. Niezwykła historia banku spermy noblistów. Warszawa: Świat Książki.

Riessman, Catherine K. 1983. Women and Medicalization: A New Perspective”, Soc Policy 14/1: 3-18.

Riska, Elianne, 2003. Gendering the Medicalization Thesis. Advances in Gender Research 10/7: 59-87. DOI: http://dx.doi.org/10.1016/S1529-2126(03)07003-6

Robertson, John A. 1994. Children of Choice: Freedom and the New Reproductive Technologies. Princeton: Princeton University Press.

Saint-Germain. Christian. 2005. Paxil blues. Montreal, QC: Les Éditions du Boréal. Saint-Hilaire, Pierre-Luc. 2006. “De l'usage "plastique” des antidépresseurs.” In Le médicament au coeur de la socialité contemporaine, edited by Johanne Collin, Marcelo Otéro, and Laurence Monnais, 109-125. Quebec, QC: Presses de l'université du Québec. 
Scanlon, Charles. 2005. The price of beauty in South Korea. BBC News, South Korea. Scott, Susie. 2006. „The medicalisation of shyness: from social misfits to social fitness." Sociology of Health \& Illness 28/2: 133-153. DOI: http://dx.doi.org/10.1111/j.1467-9566.2006.00485.x

Suissa, Amnon J. 2008. "Addiction to Cosmetic Surgery: Representations and Medicalization of the Body.” Int J Ment Health Addiction 6: 619-630. DOI: http:// dx.doi.org/10.1007/s11469-008-9164-2

Summerfield, Derek. 2001. "The invention of post-traumatic stress disorder and the social usefulness of a psychiatric category.” British Medical Journal 322: 95-98. DOI: http://dx.doi.org/10.1136/bmj.322.7278.95

Swaan (de), Abram. 1989. “The reluctant imperialism of the medical profession.” Social Science and Medicine 28: 1165-1170.

Tiefer, Leonore. 1994. “The Medicalization of Impotence: Normalizing Phallocentrism”, Gender and Society 8/3: 363-377. DOI: http://dx.doi.org/10.1177/ 089124394008003005

Timimi, Sami. 2002. Pathological Child Psychiatry and the Medicalization of Childhood. Hove: Brunner-Routledge.

Verweij, Marcel. 1999. "Medicalization as a moral problem for preventive medicine.” Bioethics 13: 89-113. DOI: http://dx.doi.org/10.1111/1467-8519.00135

Von Hagens, Günther, Whalley, Angelina. 2005. Le monde du corps: exposition anatomique des corps humains veritable. Paris: Éditions Arts et Sciences.

Walsh, Mark. 2004. Introduction to sociology for health carers. Cheltenham: Nelson Thornes.

Watkins, Elizabeth S. 2007. "The Medicalisation of Male Menopause in America." Social History of Medicine 20/2: 369-388. DOI: http://dx.doi.org/10.1093/shm/ hkm039

Wilce, James M. 2009. Language and Emotion. Studies in the Social and Cultural Foundations of Language. Cambridge: Cambridge University Press.

Wolf, Naomi. 2002. The Beauty Myth: How Images of Beauty Are Used Against Women. New York: HarperCollins.

Zola, Irving K. 1972. "Medicine as an institution of social control”, Sociological Review 20: 487-504. DOI: http://dx.doi.org/10.1111/j.1467-954X.1972.tb00220.x

-. 1983. Socio-medical inquiries: Recollections, reflections and reconsiderations. Philadelphia: Temple University Press. 